\title{
Optimization of the Polri in Reducing Middle Criminal Actions through the Police and Community Partnership Forum
}

\author{
Eko Adi Setiawan ${ }^{1}$, Evita Isretno Israhadi², \\ \{adieko42@gmail.com¹, evita_isretno@borobudur.ac.id² \\ Program Doctor of Law, Universitas Borobudur ${ }^{1}$, Faculty of Law, Universitas Borobudur ${ }^{2}$
}

\begin{abstract}
Liquor is a particular problem in the community, considering the culture of the Indonesian people considers liquor to be a cultural deviation. The purpose of this study was to determine the optimization of the police in reducing minor crimes of liquor and to find out what obstacles were faced by the police in reducing these problems. The method used in this study is qualitative, with an approach to identifying issues that exist in the community. The results of this study are that the Indonesian National Police collaborates with community leaders in community problem reduction forums, namely, alcohol which leads to minor crimes. The obstacle faced by the Indonesian National Police is the rise of alcohol parties in the community, so that there is a need for a communication forum between communities to reduce soft drink crimes.
\end{abstract}

Keywords: Reduction; Criminal Action; Community Partnership

\section{Introduction}

Indonesia is a legal state based on Pancasila. The essence of the Pancasila state law is the enforcement of justice and truth, not merely law enforcement formally [1]. Furthermore, the law does not automatically enforce justice; many people enforce the law by establishing formal truth. Still, its substance is very contrary to the sense of justice because what is built there is a law for direction, not a law for righteousness. The emergence and repetition of legal proceedings against minor cases, whose judicial processes are viewed with disapproval by the public, are not perceived as odd by law enforcers. The light case, which the community responded to, was normatively a criminal act, so the ongoing legal process should be viewed as a legal lesson [2].

Indonesia is a state of the law; therefore, everything its citizens do is regulated by applicable law [3]. With this law, there are rights and obligations. Every Indonesian citizen has the same rights before the law [4] This is handled in the Preamble of the 1945 Constitution. This right becomes an obligation for the state to protect it, both the right to live and get a decent life and the right to get fair health and education services [5]. There is no element of discrimination. In addition to appearing a right, of course, there is also an obligation, namely every citizen besides having rights protected by the state, but also should follow all the rules that have been regulated and determined by the government. To support 
the achievement of the goals and ideals of the Indonesian nation, the applicable law must be obeyed by all Indonesian citizens without exception, even if it is the head of state.

Communities live and develop in the areas they occupy, both broadly and in small spaces, namely villages. To create a community life that is safe, peaceful, and prosperous, of course, cooperation from the community itself is needed, and a leader is also required to regulate the territory. The village leadership may be held by someone who has the status of a host, a religious leader, or both. They are chosen not only because they have wider family and kinship networks but also because they control large numbers of people to cultivate their land, direct their capital, or follow their lessons [6]. Crimes that have not been handled optimally, The increasing threat of transnational crime to domestic security, The rise of drug trafficking and abuse, Increased security disturbances and violations of the law of the sea, Weak supervision and law enforcement of forest resource management- the decline in public compliance and discipline to the law, lack of professionalism of the police agency.

From the problems above, which is considered the leading cause that causes other issues is the weak professionalism of the police institution. All problems faced are expected to be overcome if the police agency is effective, efficient, and accountable. Police institutions must have professionalism in integrating structural aspects, instrumental aspects, and cultural aspects. In achieving this, human resources as the backbone of the Indonesian National Police must meet standards, both in terms of quantity and quality.

In resolving a criminal act, it begins with the examination of a criminal case, which begins with an allegation that a crime has occurred (delict) which can be in the form of a crime (rechdelict/malaperse) or a violation (westdelct/mala quia prohibia). In its development, the settlement of criminal acts outside the court can be done through the Police and Community Partnership Forum (FKPM). Compensation of criminal acts outside the court through FKPM is based on the Decree of the Chief of Police Number Skep.433/VII/2006 concerning Guidelines for the Establishment and Operationalization of Community police. FKPM is a form of Community Policing (POLMAS), a form of cooperation between the police and the community based on the Decree of the Chief of Police Number Skep. FKPM is an independent organization, independent and free from practical political influence or interference from any party.

One thing that has a lot of adverse effects is the circulation of alcohol. The illegally circulated liquor does not meet the health quality set by the Ministry of Health. However, many in society still carry out actions that have sanctions values, one of which is the circulation of alcohol. The obstacle is that there is still alcohol trade in various regions even though they have been threatened with punishment. One of them is the circulation of bootleg liquor. The trade-in bootleg liquor is news whose existence is closed from the public (hidden) because it can be punished if proven. In Indonesia, the data on crime, riots, rape, murder, traffic accidents, and brawls are increasing yearly and are triggered by alcohol. The anxiety felt by the community is the problem of alcohol because it is disconcerting the peace and security of life in society. There is no age limit on who will become victims of alcohol violence, both school-age children and workers.

\section{Methodology}

The approach in this study uses the sociological juridical method, meaning research conducted on the actual situation of society or the community environment to find facts (factfinding), which then leads to identification (problem-identification) and ultimately leads to 
completion [7]. This research is descriptive. Descriptive research is one type of research whose purpose is to present a complete picture of the social setting or explore and clarify a phenomenon or social reality by describing some variables relating to the problem and unit under study [8]. The data obtained from the study results will be analyzed using descriptive analysis methods that explain clearly with sentences to answer the problem formulation and draw conclusions deductively.

\section{Results and Discussion}

\subsection{Optimization of the National Police in Reducing Minor Crimes of Alcoholism Through Police and Community Partnership Forums}

In a society's life, sometimes problems arise that cause disruption of security and order. These problems automatically occur along with the times. For security purposes related to improving security, order, and crime prevention, problems that often arise are described: (a)Crimes that have not been handled optimally, (b) The increasing threat of transnational crime to domestic security, (c) The rise of drug trafficking and abuse, (d) Increased security disturbances and violations of the law of the sea, (e) Weak supervision and law enforcement on forest resource management, (f) The decrease in public compliance and discipline to the law, (g) Lack of professionalism of police institutions.

Of the seven problems above, which is considered the leading cause that causes other issues is the weak professionalism of the police institution. All problems faced are expected to be overcome if the police agency is effective, efficient, and accountable. Police institutions must have professionalism in integrating structural aspects, instrumental aspects, and cultural aspects. In achieving this, human resources as the backbone of the Indonesian National Police must meet standards, both in terms of quantity and quality (BAP), and the perpetrators are immediately arrested. At the same time, the police should have a consideration of every case that will be handled.

The lack of professionalism of the police agency causes a lack of public awareness in resolving a case or criminal case. Therefore, the Indonesian National Police created a program to improve police performance and to bring police officers closer, especially in areas such as Polsek with the community. The security potential empowerment program aims to bring the police closer to the community so that the community is encouraged to cooperate with the police through guidance to the community in assisting the main task of the police to create security and public order.

The duties and functions of the police in the context of protecting the community require members of the police at the Polsek to have insight and understanding of the characteristics of the environment in which they are assigned. Good insight and understanding of the features of the environment in which they work is a capital that can be utilized to facilitate the police to build better social relations with the community. This can be seen from the community recognition of police officers in their environment and the way people contact police officers when they need police assistance and service [9].

Thus the results of the study can contribute to the settlement of minor crimes based on justice, as expected by the community. The urgency of the existence of a system for resolving petty crimes that do not generalize the actions and perpetrators of crimes, with alternative cultural reconstruction, especially the reconstruction of legal/juridical thinking, can be shown from the gap/absence of legal synchronization between simple judicial principles, fast and low 
cost (Article 2 paragraph (4) of Law No. 48 of 2009) with the meaning of law enforcement officers regarding the regulation of the settlement of criminal cases as regulated in Law No. 8 of 1981 concerning the Criminal Procedure Code (in the future referred to as abbreviation KUHAP). Among the principles of case settlement with a restorative justice approach, penal mediation, and a community policing strategy that is the basis for resolving cases through FKPM is deconstructing criminal acts into social problems/problems involving the parties. This deconstruction was marked by non-compliance with case signs which were the authority of FKPM, which were regulated in a limited manner in the Chief of Police Decree No. 433 of 2006 by FKPM management.

The results of the study found evidence - evidence of these deviations. Conditions for cases that can be resolved through FKPM (a) Not cases that stand out / get the public's attention, such as cases of rape, murder, and others; (b) The willingness of the parties, especially the victims, to settle amicably and free from pressure; (c) The perpetrator can still be fostered; (d) The family of the perpetrator/perpetrator is willing to apologize to the family of the victim/victim; (e) The perpetrator is willing to compensate for the loss; (f) Minor cases that cause difficulties in submitting evidence in court, such as banana theft. The criteria for claims that are resolved through FKPM are:

a. Taking into account the socio-economic conditions of the actors

b. This is the first time that the perpetrator has committed a crime (first offender) which is estimated to be able to be fostered;

c. The perpetrator admits the crime committed

d. Willing to compensate for losses as a form of good faith

e. Promise not to repeat his actions

The two opinions above emphasize that the criteria for minor crimes that will be resolved through FKPM are seen from the objective side (actions) and consider the subjective aspect, namely the aspects attached to the perpetrator. Additional requirements developed in practice, if the two opinions are combined and formulated in a theoretical formulation, the conditions related to the actor can be formulated as follows:

a. Willingness to apologize to the victim/victim's family;

b. Willingness to compensate

c. Socio-economic conditions

d. First time committing a crime (first offender)

e. The perpetrator admits the crime committed

f. Willing to pay for the loss as a form of good faith

g. Promised not to do it again.

The research findings above show conformity between the research results and the theoretical framework regarding the principles of case resolution through restorative justice, penal mediation, and the community policing approach implemented in case of solution through FKPM. The advantages of these findings can be compared for the same reasons regarding criminal law. From the point of view of criminal law, forgiveness becomes complex/complicated because the grounds are limited in the law, such as the reasons for eliminating criminals in the Criminal Code. The mechanism is that FKPM administrators, in practice, develop their case settlement mechanism by considering the nature of the case and the parties' dignity. The results of the study also found weaknesses/limitations in resolving issues through FKPM. On the other hand, there are also advantages/supporting capacity, which are the advantages of resolving cases through FKPM at the research location.

A problem is a condition or situation that creates a need or dissatisfaction in people who want help or improvement. Meanwhile, a problem will become a public problem if it involves 
many people and impacts the people who are directly involved and a group of other people who are indirectly involved. So it can be interpreted that public problems are problems that have a broad impact and include consequences for people who are not directly involved. In an era where information can be accessed easily and quickly, of course, we know that recently the alcohol party culture has flourished in Indonesia. Not only in big cities but in remote villages, the phenomenon of binge drinking often occurs. Several events of alcohol parties often appear in the media because these alcohol parties often have the effect of other events that lead to crime or the emergence of victims

From the definition of public problems above and the position of alcohol parties in society, of course, we can classify alcohol parties as a general problem that must be dealt with together, which must be handled systematically, structurally, and seriously by the government and the community. Because if left unchecked, the effect will be on people who are partying alcohol and other community members around them. For this reason, the government as a social institution in society must take action, starting from the functioning of the control role of institutions and institutions in charge of making public policies that can suppress or eliminate the phenomenon of this alcohol party.

As we all know, the institution that has the task of maintaining security and public order in Indonesia is the National Police, as mandated by Law no. 2 of 2002 concerning the police. Suppose this alcohol party is a phenomenon that makes people uneasy and is a public problem. In that case, we can conclude that this event is contrary to the values and norms that apply in society. And if the National Police is an institution that is part of a social institution tasked with keeping people's behavior following applicable values and norms, then the National Police should take systematic and structured steps to overcome the problem of this alcohol party.

To get the right solution, we must first know the phenomenon of binge drinking in-depth, the social views of the community regarding this, and the factors that support binge drinking. The main point of the National Police so that in carrying out the handling, it is not wrong and on target under the authority given by the government. Finally, we must formulate concrete steps that are structured and systematic so that the function of the National Police as an institution to maintain security and order can carry out its obligations properly following what is mandated by the government as an extension of the people.

\subsection{Obstacles Faced by Polri's Optimization in Reducing Minor Crimes of Alcoholism Through Police and Community Partnership Forums}

As we all know, alcohol parties bring harmful effects for the perpetrators and adversely affect residents who are not directly involved in them. Examples can be seen from several crime events that occur after people drink alcohol, like the thuggery that happened on the streets where there was often extortion against residents after some people had binge drinking. Alcohol, an ingredient in liquor, has a specific effect so that the drinker cannot control his behavior correctly. Several factors certainly support the number of alcohol party events in the community. The number of alcohol parties, of course, does not just happen. The ease with which people get liquor makes it easy for some people to drink alcohol. If we look at several events, this alcohol party is carried out by people from old age to high school children who are only a dozen years old. This happens because people can buy liquor easily in convenience stores. Liquor products such as beer with alcohol content below $5 \%$ by the government are allowed to be sold freely in minimarkets close to residential areas. Then the problem arises that it is difficult for social institutions to supervise because the location of minimarkets is 
scattered everywhere and makes people able to drink it anywhere. Not to mention the added number of stalls for illegal drinks that appear in several community settlements. Semipermanent sales places even sell drinks whose levels are even higher than $55 \%$. The ease of access to liquor has become one of the factors supporting the number of alcohol parties in the community.

Another supporting factor for the rise of alcohol parties in the community is the circulation of illegal alcohol. A liquor allowed to be sold by the government is a drink with a maximum content of $55 \%$, and its circulation is regulated by government regulation. This implies that the government has set up a control mechanism for the circulation of liquor according to the level so that the effects of the drink can also be controlled. Many liquors circulating in Indonesia do not meet the regulations required in the law where the drinks enter Indonesia illegally or are even made unlawfully in the country. Glasses made in the country illegally, such as rat stamp, white wine, you, and others. Illegal manufacture, of course, makes it impossible for the product to be sold legally. For that reason, this type of liquor is usually sold at liquor stalls or herbal medicine, whose existence does not have a permit from the government. This, of course, makes supervision by the government even more difficult to do. And the lack of leadership makes it difficult for the government to control the adverse effects caused.

The third factor is the government's lack of serious attention to the problem of liquor, which is indicated by the lack of strict government public policies that regulate the issue of alcohol. The police, as law enforcers, can only control criminal acts that violate favorable laws that the lawyer has handled. Some of the problems are that the police have difficulty taking action against drink sellers who sell carelessly in residential areas. Although the sale of liquor in residential areas is deemed socially inappropriate because it will harm children, this is not regulated in a criminal offense but is only included in the category of wrong. So when they find liquor stalls around the settlement, the police can do nothing but wait for the person who drank the liquor to commit a crime and then arrest him. Suppose the government pays serious attention to this problem. In that case, the government should formulate an appropriate public policy and then apply it in the form of a law to take action by the police.

The next factor causing the rampant alcohol parties is the lack of performance of the apparatus in carrying out systematic steps to deal with this public problem. The device's actions related to controlling the circulation and sale of liquor can be classified as still low. Raids that are felt to suppress the circulation of illegal liquor and alcohol parties are usually only carried out before the month of Ramadan and are very rarely carried out in other months. And finally, the community considers it natural that alcohol parties are rampant because the police are less than optimal in carrying out their duties.

Seeing the phenomenon of binge drinking as a public problem means seeing a general problem that must be resolved by the government, which is the unity of the executive, judicial, and legislative functions. This means that there must be cooperation starting from making ideal public policies that regulate the circulation of alcohol, implementing general procedures by the executive function, and law enforcement consistent with existing regulations. The National Police, as one of the elements of the government as mandated by Law No. 2 of 2002, has the task of maintaining public security and order, enforcing the law, and providing protection, shelter, and services to the community. This means that the National Police, as one of the government institutions, is tasked with maintaining security and public order by enforcing the applicable law. However, not all rules can be handled by the police, only acts that fall into the realm of criminal law that the police can enforce. For this reason, the author invites us to examine the phenomenon of binge drinking from a legal perspective, be it in terms of criminal law or others. 
According to the Criminal Code (KUHP), Article 492 paragraph (1), which reads, "Anyone drunk in public obstructs traffic, or disturbs order, or threatens the safety of others, or does something that must be done with care. being careful or by taking certain precautions beforehand so as not to endanger the life or health of others, is threatened with a maximum imprisonment of six days, or a maximum fine of three hundred and seventy-five rupiahs." Here, a criminal threat for drunk people who disturbs public order has been regulated, but there is no criminal threat for drunk people who remain silent and do not interfere with the public interest. This article implies that the National Police can only enforce the law after an incident that disrupts public order.

According to the Food Law No. 18 of 2012, the National Police have the duty and authority to control the food that does not have a distribution permit as stated in Article 142, which reads "Food Business Actors who intentionally do not have a distribution permit for any Processed Food made domestically or which are imported for trading in retail packaging, shall be punished with imprisonment for a maximum of 2 (two) years or a fine of a maximum of Rp. 4,000,000,000.00 (four billion rupiah)." From this article, we can conclude that the National Police controls the circulation of illegal or unauthorized food in Indonesia. The law also explains that alcoholic beverages are included in the food category referred to by this law. So it is clear that the National Police obliged and has the right to regulate the circulation of illegal liquor or those that do not have a distribution permit. This, of course, can support efforts to overcome alcohol parties because, based on the fact that alcohol parties that occur in Indonesia mostly use illegal drinks, both locally made and illegally imported products.

The two laws above are the legal umbrella for the National Police in enforcing laws relating to liquor. It includes the authority and the obligation for the National Police to participate in carrying out a series of efforts to deal with the alcohol problem. So, the success or failure of the government's and community's efforts to deal with the alcohol party problem depends also on how the police are involved in carrying out their functions.

\section{Conclusion}

In a society's life, sometimes problems arise that cause disruption of security and order. These problems automatically occur along with the times. The lack of professionalism of the police agency causes a lack of public awareness in resolving a case or criminal case. Therefore, the National Police of the Republic of Indonesia made a program to improve police performance and to bring police officers closer, especially in areas such as Polsek with the community. As we all know, alcohol parties bring harmful effects for the perpetrators and negatively affect residents who are not directly involved in them. Examples can be seen from several crime events that occur after people drink alcohol, like the thuggery that happened on the streets where there was often extortion against residents after some people had binge drinking. Alcohol, an ingredient in liquor, has a particular effect so that the drinker cannot control his behavior correctly. Several factors certainly support the number of alcohol party events in the community.

The number of alcohol parties, of course, does not just happen. The ease with which people get liquor makes it easy for some people to drink alcohol. If we look at several events, this alcohol party is carried out by people from old age to high school children who are only a dozen years old. This happens because people can buy liquor easily in convenience stores. Liquor products such as beer with alcohol content below $5 \%$ by the government are allowed to be sold freely in minimarkets close to residential areas. Then the problem arises that it is 
difficult for social institutions to supervise because the location of minimarkets is scattered everywhere and makes people able to drink it anywhere. Not to mention the added number of stalls for illegal drinks that appear in several community settlements. Semi-permanent sales places even sell drinks whose levels are even higher than $55 \%$. The ease of access to liquor has become one of the factors supporting the number of alcohol parties in the community.

\section{References}

[1] E. E. Supriyanto, "Revitalization of Pancasila as a Solution to The Problems Faced by The Indonesian Nation," J. Pendidik. Nusant., vol. 1, no. 2, pp. 52-61, 2021.

[2] V. Venditti, The Law and Politics of Inclusion. 2019.

[3] A. F. Sumadi, "Hukum dan Keadilan Sosial dalam Perspektif Hukum Ketatanegaraan," J. Konstitusi, vol. 12, no. 4, p. 849, 2016, doi: 10.31078/jk1249.

[4] M. Muladi and S. Suparno, "Indonesian Legal Reform Based on Pancasila," 2021, doi: 10.4108/eai.6-3-2021.2306451.

[5] M. Hariyanto and A. Budianto, "Protection of Indigenous Peoples Law Based on the 1945 Constitution,” 2021, doi: 10.4108/eai.6-3-2021.2306460.

[6] S. Syarif and S. Suparno, "Legal Ideal of Pancasila on Legal Politic in the Formulation of Laws and Regulations," 2021, doi: 10.4108/eai.6-3-2021.2306458.

[7] W. M. K. Trochim, Research Methods. 2019.

[8] C. Maguire, "Library research: Luxury or necessity?," Aust. Libr. J., vol. 60, no. 4, pp. 298-303, 2011, doi: 10.1080/00049670.2011.10722646.

[9] E. E. Supriyanto, M. Rachmawati, and F. J. Nugroho, "Transformative Policies and Infrastructure Strengthening Towards the Police Era 4 . 0,” J. Bina Praja, vol. 13, pp. 231-243, 2021. 